\title{
Aparecer(es): la estética de los movimientos sociales. El caso del Frente Popular Darío Santillán Rosario (Argentina, 2004-2012)
}

\author{
Appear(ances): the aesthetics of social movements. The case of the Frente \\ Popular Darío Santillán Rosario (Argentina, 2004-2012)
}

\author{
Marilé Di Filippo*
}

\begin{abstract}
Resumen: El propósito de este artículo consiste en reflexionar sobre un aspecto, escasamente explorado, de las múltiples vinculaciones entre arte, estética y política. Precisamente, abordamos una dimensión de la estética de la política, a saber: las formas de aparición en el espacio público de los movimientos sociales, en este caso, del Frente Popular Darío Santillán Rosario, una organización social de la ciudad de Rosario (Argentina), durante el período 2004-2012. Analizamos diferentes componentes de dicha dimensión, a saber: a) la configuración de una dramaturgia piquetera, que entendemos como la utilización dramática de elementos emblemáticos de la gramática política piquetera; b) el proceso de carnavalización de la protesta, en otros términos, la constitución de una forma de aparecer festiva en el espacio público; y c) la esfera mística de su política, es decir, prácticas organizadas de tipo celebratorias de motivación y renovación de la fe y el compromiso político. Como hipótesis proponemos que, en la composición y recreación de la dimensión estética de la política, en la fabulación de esas formas de aparecer en el espacio público se dirime buena parte de la configuración de la subjetividad colectiva de dicho movimiento social. En otras palabras, sostenemos que el proceso de subjetivación colectiva del Frente Popular Darío Santillán Rosario, implicó complejos procesos de subjetivación estética.
\end{abstract}

Palabras clave: estética política, movimientos sociales, Frente Popular Darío Santillán Rosario, protesta social, Argentina

\begin{abstract}
The purpose of this article is to reflect on an aspect, scarcely explored, of the multiple links among art, aesthetics and politics. Particularly, we analyse one dimension of the aesthetics of politics, namely: the forms of appearance of social movements in the public space, in this case, the Frente Popular Darío Santillán Rosario, a social organization of the city of Rosario (Argentina), between 2004 and 2012. We analyze
\end{abstract}

\footnotetext{
* Argentina. Docente e investigadora. Doctora en Ciencias Sociales por la Universidad de Buenos Aires (UBA), Magíster en Estudios Culturales y Licenciada en Ciencia Política por la Universidad Nacional de Rosario (UNR). Becaria posdoctoral del Consejo Nacional de Investigaciones Científicas y Técnicas (CONICET). E-mail: mariledifilippo@gmail.com. Pertenencia institucional: CONICET - UNR - UBA - UCSF.

Este artículo es fruto de la investigación doctoral financiada por el CONICET. La Tesis Doctoral se denominó "Estéticasen-las-calles rosarinas. Del taller a los movimientos sociales: prácticas, repertorios e itinerarios estético-políticos en la década del 2000" y fue defendida en el mes marzo del año 2016 en la Universidad de Buenos Aires.
} 
different components of this dimension, namely: a) the configuration of a piquetera dramaturgy which we understand as the dramatic use of emblematic elements of the piquetera political grammar; b) the carnivalization process of protest, in other words, the constitution of a festive form of appearing in the public space; and c) the mystical dimension of its politics, that is, organized celebratory practices of motivation and renewal of faith and political commitment. We propose the hypothesis that in the composition and recreation of the aesthetic dimension of politics, in the fabulation of these forms of appearing in the public space, a large part of the configuration of the collective subjectivity of this social movement is settled. In other words, we argue that complex processes of aesthetic subjectivity have been involved in the collective subjectivation of the Frente Popular Darío Santillán Rosario.

Keywords: political aesthetics, social movements, Frente Popular Darío Santillán Rosario, social protest, Argentina

Recibido: 26 enero 2018

Aceptado: 8 abril 2018

\section{Introducción}

En el campo de estudios en torno a las vinculaciones entre arte, estética y política en Argentina se han desarrollado valiosas investigaciones que abordan los modos en que las formas artísticas intervienen en el terreno de la política. En efecto, una prolífera variedad de trabajos se ha abocado a reflexionar, de modo diverso, en torno a la politicidad del arte o acerca de los modos en que el arte a partir de sus producciones hace política (Kozak, 2004; Moret, 2006; Giunta, 2009; AA.VV., 2010; Lucena, 2015; Vázquez, 2011, por nombrar solo algunos). Investigaciones como las de Ana Longoni sobre los cruces entre arte y política y, especialmente, sobre activismo artístico han abierto interrogaciones e inaugurado discusiones fundamentales acerca de la complejidad de estas dilemáticas interfaces (Longoni, 2005, y 2009; Longoni y Bruzzone, 2008; Longoni y Mestman, 2000, etc.).

Por otra parte, han sido escasas las propuestas destinadas a desentrañar los modos en que la política se configura estéticamente, entre las que podríamos citar los trabajos sobre escenificación o dramatización del poder (Balandier, 1994; Blair, 2005; Uribe, 2004, entre otros). Dentro de estas últimas, han sido exiguas las investigaciones que no le han atribuido a dicho componente estético un carácter negativo asociado a la manipulación o al engaño, y muy pocas las interpretaciones que destinaron esfuerzos a pensar el trabajo sobre esta configuración estética como una necesidad clave de las gramáticas de la resistencia ${ }^{1}$.

\footnotetext{
${ }^{1}$ Entendemos por resistencias a las imaginaciones y experimentaciones políticas, con modulaciones organizativas diversas, que interpelan el plano de inmanencia dominante y cuestionan, entonces, la distribución policial de lo sensible vigente. No reducimos las resistencias al acto de negación o confrontación con el orden dado, sino que destacamos, especialmente, su fuerza creativa que posibilita, emancipatoriamente, el devenir de nuevos modos de vida obturados por el orden social imperante.
} 
Por nuestra parte, siguiendo a Jacques Rancière ${ }^{2}$, consideramos que la política es necesariamente estética, en otros términos, que estética y política mantienen una relación de principio, a priori. Dicha condición estética se despliega en las diversas prácticas políticas que implican capacidades compositivas, de montaje y de percepción de escenarios y que suponen la utilización de recursos y habilidades creativas, poiéticas de invención de nuevos espacio-tiempos, escenas, personajes, argumentos, que no las convierten en prácticas artísticas pero que sí manifiestan esta encarnadura. Si bien, inspirados en esta definición, toda práctica política es en sí misma estética, nos interesa analizar una serie de prácticas que componen formas de aparición en el espacio público, dramaturgias, que reivindican por sobre el componente estético inescindible de toda acción política, un plus estético, un algo más que no es, empero, simplemente artístico. Son prácticas que oscilan ambiguas entre ambos dominios, que se resisten a diferenciaciones estrictas y que reafirman la complejidad de los vínculos entre arte, estética y política.

La insurrección popular argentina del 2001 inauguró una década de sentidas innovaciones en los modos de hacer arte y política. Significó el nacimiento de un nuevo protagonismo social con una insoslayable singularidad poética e innovados modos de estar en la calle. Fue un acontecimiento umbral en la historia política argentina reciente y el punto de ebullición de un ciclo de protesta que situamos entre los años 1997 y 2003/5, en línea con lo que indican diversos teóricos de la acción colectiva ${ }^{3}$. Este ciclo se distinguió por diferentes procesos de lucha, entre ellos el protagonizado por los trabajadores desocupados, popularmente conocido como movimiento piquetero debido a que una de sus metodologías de protesta más frecuentes fue el piquete, es decir, los cortes de ruta o calles durante prolongados períodos de tiempo. La ciudad de Rosario, ubicada en la provincia de Santa Fe, Argentina, fue, en esos años, cuna de un frondoso laboratorio de prácticas estético-políticas. Se conformaron diferentes colectivos de activismo artístico que, junto con otras prácticas gráficas, performáticas, festivas de otros actores sociales y políticos, alumbraron nuevos modos de producción, circulación, "pensabilidad" y afección estéticopolítica.

A mediados de la década del 2000 comienza otro ciclo de protesta en Rosario y también en otras ciudades importantes del país como Buenos Aires. Este período, caracterizado por un contexto de recomposición institucional, luego de la asunción del Presidente Néstor Kirchner, y de mejora de las condiciones sociales y económicas, ha sido considerado como un momento de repliegue de la escena callejera, de reflujo o de "impasse" para las organizaciones sociales que habían protagonizado el momento anterior. Fue un ciclo con características beligerantes claramente diferentes al que lo antecedió, con importantes desafíos para los movimientos sociales. Fueron necesarias nuevas coreografías

\footnotetext{
${ }^{2}$ Jacques Rancière, Sobre políticas estéticas, Barcelona, Universidad Autónoma de Barcelona, 2005.

${ }^{3}$ Maristella Svampa, "Argentina: Una cartografía de las resistencias (2003-2008). Entre las luchas por la inclusión y las discusiones sobre el modelo de desarrollo", Observatorio Social de América Latina, Vol. X, Buenos Aires, 2008. Y María Rosa Herrera, "La contienda política en Argentina 1997-2002: Un ciclo de protesta", América Latina Hoy, $\mathrm{N}^{\circ} 48$, Salamanca, 2008.

${ }^{4}$ Colectivo Situaciones, (coord.), Impasse: dilemas políticos del presente, Buenos Aires, Tinta Limón, 2009.
} 
para afrontar un proceso en el que los modos de aparecer perdían sentidamente legitimidad e incluso posibilidades de visibilidad y enunciabilidad.

El Frente Popular Darío Santillán Rosario (FPDS) fue parte de un movimiento social a nivel nacional, que surgió en el año 2004 con una obligada apuesta estética en sus repertorios de protesta. Las primeras articulaciones para la conformación de la organización tuvieron lugar hacia el año 2002, posteriormente a la Masacre de Avellaneda que fue una feroz represión policial desatada en la Estación de trenes de Avellaneda, el 26 de junio de ese año, cuando organizaciones sociales, principalmente piqueteras, de diferentes partes de la provincia de Buenos Aires cortaron el Puente Pueyrredón. La represión tuvo como saldo 33 heridos con balas de plomo, casi un centenar con balas de goma y otros elementos, y 2 muertos: Darío Santillán y Maximiliano Kosteki que pertenecían al Movimiento de Trabajadores Desocupados de Lanús y Guernica respectivamente, organizaciones nucleadas en la Coordinadora de Trabajadores Desocupados “Aníbal Verón”.

Se inscribió en una perspectiva política autonomista y multisectorial ya que propuso, ante la recomposición del sistema político, la necesidad de integrar una serie de luchas populares dispersas. Se compuso de organizaciones de desocupados o piqueteras, muchas de Buenos Aires, las que tuvieron el mayor peso cuantitativo y cualitativo además del impulso inicial para su constitución ${ }^{5}$. Asimismo, estuvo integrado por agrupaciones estudiantiles independientes, con fuerte presencia de las de Rosario, Tucumán, Neuquén y Córdoba; por un incipiente sector rural y de trabajadores ocupados, principalmente en el sur del país; por colectivos y trabajadores de la cultura de Buenos Aires y La Plata y por activistas de las redes de trueque y organizaciones vecinales, principalmente de la provincia de Salta.

El común denominador de este variopinto espectro de actores fue su definición como anti-imperialistas y anti-capitalistas, a lo que en 2007 sumaron su carácter antipatriarcal. Y, sobre todo, por ser organizaciones que desde sus diferentes territorios habían participado activamente del ciclo de protesta y los procesos de resistencia abiertos en 1997. El FPDS de la ciudad de Rosario, del que nos ocuparemos aquí, fue parte, como asevera Svampa ${ }^{6}$, de una nueva generación militante, un nuevo ethos, en el que la dimensión cultural $^{7}$, en términos amplios, ocupó un lugar central. Desarrolló una serie de prácticas

\footnotetext{
${ }^{5}$ Según detalla Fornillo ellas fueron los diversos MTDs que formaban parte del MTD Aníbal Verón (MTD Lugano y MTD "Darío Santillán" de Ciudad de Buenos Aires, los MTD "Darío Santillán" de Alte. Brown, MTD Berisso, MTD "Javier Barrionuevo" de Esteban Echeverría, MTD Ezeiza, el MTD "Oscar Barrios" de José C. Paz, MTD La Cañada, MTD Lanús, MTD La Plata, MTD Lomas de Zamora, MTC Luján, todos de la Provincia de Buenos Aires. Y, por último, en la Provincia de Río Negro, el MTD "Darío Santillán"). También entre ellos estaba el Movimiento de Unidad Popular (MUP); la Unión de Trabajadores en Lucha Sur (UTL Sur); el MTD La Verdad, el Movimiento Resistir y Vencer 26 de Junio; el Centro Popular Agustín Tosco y la CTD Aníbal Verón "Trabajo y Dignidad" de F. Varela.

${ }^{6}$ Maristella Svampa, "Argentina, una década después. Del 'que se vayan todos' a la exacerbación de lo nacional-popular", Nueva Sociedad, $\mathrm{N}^{\circ}$ 235, Buenos Aires, 2011.

${ }^{7}$ A nivel nacional el FPDS tuvo una fuerte impronta en este sentido. La Estación Avellaneda, luego re-nombrada como Estación Darío y Maxi, alojó una prolífera actividad cultural. Por ejemplo, las vigilias que se celebraron cada año para construir la memoria política de la Masacre fueron instancias de gran desarrollo cultural como así también la Muestra de Arte permanente que desde el 2006 se convoca con este mismo objetivo. Asimismo, los espacios culturales tuvieron un papel destacado en la actividad política de la organización.
} 
estético-políticas, específicamente artísticas, de raigambre visual, performática y festiva. Incluso, constituyó su propio colectivo artístico, denominado Digna Rabia.

Ahora bien, aquí no nos ocuparemos de ellas, sino que nos disponemos a indagar prácticas no necesariamente artísticas que renovaron sus formas de aparecer en el espacio público. En lo que sigue analizaremos tres de los aspectos más significativos de la dimensión estética del FPDS Rosario durante el período comprendido entre los años 2004 y 2012. El primero consiste en la generación de una dramaturgia piquetera que entendemos como la utilización dramática de elementos emblemáticos de la gramática política piquetera en pleno momento de desaparición del sujeto piquetero de la escena política nacional -e incluso en las filas del movimiento- y del piquete como metodología de protesta. En segundo lugar, del proceso de carnavalización de la protesta, o sea, la constitución de una forma de aparecer festiva en el espacio público que rompió, ambiguamente, con la estética sacrificial de la militancia de décadas anteriores. Por último, analizaremos el despliegue de su esfera mística.

Como hipótesis proponemos que, en la composición y recreación de la dimensión estética de la política, en la fabulación de esas formas de aparecer en el espacio público se dirime buena parte de la configuración de la subjetividad colectiva de los movimientos sociales, en este caso del FPDS Rosario. En otros términos, sostenemos que el proceso de subjetivación colectiva del movimiento implicó complejos procesos de subjetivación estética.

En cuanto a nuestra metodología y al modo en que abordaremos esta hipótesis, reconociendo e intentando erradicar la violencia epistémica ${ }^{8}$ que anida a menudo en las prácticas investigativas, diagramamos una metodología singular, que consideramos "ensamblada" ya que convivieron y se articularon elementos heterogéneos devenidos de las propuestas críticas y decoloniales ${ }^{9}$ con recursos o técnicas propias de las metodologías más habituales. Su ensamblaje se fundó en lo que llamamos una "política del trato" que refiere, en primer lugar, a una ética del cuidado ${ }^{10}$ respecto de aquellos con quienes nos relacionamos en el vínculo investigativo $\mathrm{y}$, en segundo lugar, alude al des-trato de las herramientas clásicas desde una lógica de interacción que desdibuja la posición clásica del sujeto investigador y del objeto investigado ${ }^{11}$. Concretamos numerosas conversaciones ${ }^{12}$, encuentros individuales y grupales, recogimos testimonios, realizamos treinta entrevistas en profundidad -que fueron desgrabadas, enviadas e intervenidas por los entrevistados-. Efectuamos observaciones participantes en diversas actividades llevadas a cabo por la

${ }^{8}$ Alejandro Haber, "Nometodología payanesa. Notas de metodología indisciplinada", Revista Chilena de Antropología, $\mathrm{N}^{\circ}$ 23, Santiago, 2011.

${ }^{9}$ Con el término decolonial referimos a propuestas epistemológicas, dentro de la teoría crítica contemporánea, que deconstruyen, analizan críticamente e interpelan la matriz del poder colonial en el ámbito del conocimiento. Proponen nuevas miradas que cuestionan las jerarquías epistémicas globales y estimulan la producción de conocimiento desde una posición situada en la especificidad histórica y política del investigador.

${ }^{10}$ Carlos Figari, "Conocimiento situado y técnicas amorosas de la ciencia. Tópicos de epistemología crítica", Cinta de Moebio, Revista de Epistemología de Ciencias Sociales, Santiago, 2011.

${ }^{11}$ Donna Haraway, Ciencia, cyborgs y mujeres. La reinvención de la naturaleza, Madrid, Cátedra, 1995.

${ }^{12}$ Haber, op.cit., 24. Para el autor la conversación es “(...) un flujo de agenciamientos evestigiales intersubjetivos que crea subjetividades en relación; (que) no se recorta por el intercambio lingüístico ni por la humanidad de los interactuantes, sino todo lo contrario, no se está en conversación en calidad de hablante sino de ser o, mejor, de estarse siendo". 
organización de carácter público y privado (manifestaciones, festivales, acampes, escraches, asambleas, reuniones políticas y sociales, viajes, campañas públicas, intervenciones artísticas, etc.). También consumamos un análisis interpretativo de documentos escritos, fotográficos y audiovisuales de carácter público, y otros pertenecientes a archivos organizacionales y privados pertenecientes a militantes. Finalmente, analizamos publicaciones de la organización y realizamos un trabajo hemerográfico de los medios gráficos Rosario 12, El Ciudadano, La Capital e Indymedia. Dicha estrategia metodológica y las diferentes técnicas utilizadas responden a un trabajo de investigación más amplio en el que se inscribe este artículo ${ }^{13}$. Para esta ocasión, nos basamos, fundamentalmente, en el análisis de las entrevistas en profundidad y en las observaciones realizadas, y subsidiariamente en el análisis de algunos documentos escritos, fotográficos y audiovisuales.

\section{La dimensión estética: notas para una discusión contrariada}

Nos interesa aquí reconstruir una discusión cara a las reflexiones en torno a esta temática. Nos referimos a la diferencia entre considerar a la política como ontológicamente estética o como una característica o condición de época. Para ello repondremos las posiciones encontradas de Walter Benjamin y Jacques Rancière sobre las que se dibuja buena parte del mapa de interpretaciones para luego, con aportes de otros teóricos, trazar una cartografía más extensa de tensiones derivadas de este tópico y que orientaron nuestra investigación.

Para Benjamin ${ }^{14}$, en la era de su reproductibilidad técnica, el arte se ha despojado del halo de lo bello. Se han transformado sus formas de producción, percepción y recepción y puede ser funcional a la estetización de la política, a la que debe contraponerse la politización del arte. La estetización de la política obedece a las coordenadas históricas de la época. Es un proceso directamente asociado a las posibilidades de reproducción técnica de artes como la fotografía o el cine y a "un momento específico de la historia del poder" 15 . En dicha época se ha atrofiado la condición aurática de la obra, se ha producido el pasaje desde su función cultual a una de tipo exhibitivo, que ha permitido mayor accesibilidad y masividad, pero también ha favorecido la utilización de estas artes y sus dispositivos técnicos por parte de regímenes como el fascismo. Los espectadores reciben proyectiles, afecciones táctiles y construyen una posición de recepción no exenta de ambivalencia, en tanto oscilan entre su condición de peritos y su condición de meros consumidores pasivos de espectáculos, de distracciones que el capitalismo genera en aras de producir fascinación.

En consecuencia, la estetización de la política remite a la utilización de las artes por parte del fascismo en función de la construcción de su aparato de poder. El fascismo ha comprendido con claridad que el arte en esta nueva era ha alterado también las propias condiciones de la praxis política. Ha entendido que puede dar lugar a la estrella de cine

\footnotetext{
${ }_{13}^{13}$ Aludimos a la Tesis Doctoral que referenciamos en la nota al pie número 1.

${ }^{14}$ Walter Benjamin, "La obra de arte en la época de su reproductibilidad técnica", Discursos interrumpidos I, Madrid, Taurus, 1973.

${ }^{15}$ Christian Ruby, Rancière y lo político, Buenos Aires, Prometeo Libros, 2011, 72.
} 
pero también al dictador. El punto culminante de este devenir es para Benjamin la conversión de la humanidad en espectáculo de sí misma y su propia destrucción como motivo de goce estético de primer orden. Proceso que se encamina hacia la guerra que "permite proveer de una meta a los movimientos de masas de gran escala y mantener, al mismo tiempo, las relaciones de propiedad habituales"16. Por consiguiente, para Benjamin la política ha sido estetizada o subordinada a la lógica del espectáculo.

Rancière disiente con esta postura y considera que no hubo estetización de la política en la era de las masas, sino que ésta es necesariamente estética. Y, por otra parte, la estética que está en la base de la política difiere de la estetización pensada por Benjamin. Plantea que "esta estética no puede ser comprendida en el sentido de una captación perversa de la política por una voluntad de arte, por el pensamiento del pueblo como obra de arte"17.

Didi-Huberman insiste en señalar algunos matices respecto de esta interpretación, principalmente, a partir de una relectura de algunos pasajes de "La obra de arte en la época de su reproductibilidad técnica" que fueron eliminados de la versión más difundida, publicada, por primera vez, en 1938. A su entender, la posición de Benjamin reviste otra complejidad ya que paralelamente a la estetización de la política producida por el poder, plantea que "los pueblos han decidido exponerse a sí mismos de una manera más radical y

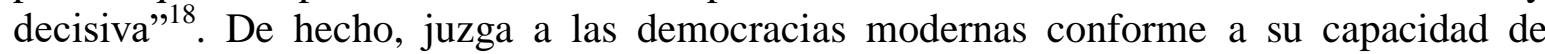
aparecer, que puede conducir a lo mejor o a lo peor "según los pueblos sean simples juguetes puestos en escena por un jefe (...) o los auténticos actores de su exposición" "19. De allí se deduce que, para Benjamin, los pueblos pueden y deben construir sus apariciones.

Volviendo a Rancière la estética de la política refiere a que la política tiene su estética propia, como composición y percepción de lo visible y lo invisible y en tanto supone la creación de espacios disensuales, de escenas y personajes, de manifestaciones y enunciaciones, que no necesariamente suponen creaciones del arte. En consecuencia, la política es ontológicamente estética.

Ahora bien, a nuestro entender esa dimensión estética de la política no posee siempre la misma densidad, la misma textura, sino que esas escenas, personajes y manifestaciones revisten en ocasiones un espesor creativo -mas no necesariamente artístico dado los regímenes de identificación y pensamiento de las artes vigentes-.

Es en este punto engorroso de la discusión que nos servimos de Boris Groys, quien tensa la discusión en dos puntos. En primer lugar, asevera que usualmente se suele celebrar la pérdida de autonomía del arte cuando su predisposición a saltar los confines del sistema artístico está motivada por el deseo de transformación social, lo que supone una motivación ética. Y que, por el contrario, tiende a reprobarse cuando esos intentos parecen ir más allá de la esfera estética y no se proponen cambiar el mundo sino hacerlo lucir mejor, a lo que se suele atribuir intenciones de seducción, manipulación, engaño u ocultamiento ${ }^{20}$.

\footnotetext{
${ }^{16} \mathrm{Ibid}, 72$.

${ }^{17}$ Jacques Rancière, El reparto de lo sensible. Estética y política. Santiago, LOM Ediciones, 2009, 10.

${ }^{18}$ Georges Didi-Huberman, Pueblos expuestos, pueblos figurantes, Buenos Aires, Manantial, 2014, 28.

${ }^{19}$ Ibid, 28.

${ }^{20}$ Boris Groys, Volverse público. Las transformaciones del arte en el ágora contemporáneo, Buenos Aires, Caja Negra Editora, 2014, 41.
} 
Este es un tópico con el que acordamos. Groys manifiesta:

Se puede hablar acerca del diseño del poder, pero también del diseño de la resistencia o (...) de los movimientos políticos alternativos. (...) Bajo el régimen del diseño moderno, el posicionamiento visual de un político en el campo de los medios masivos es justamente el que hace una afirmación crucial sobre su acción política -o incluso la constituye como tal-. El contenido, en cambio, es completamente irrelevante, porque cambia constantemente. Por lo tanto, el público general no está (...) equivocado al juzgar a un político de acuerdo a su apariencia, es decir, de acuerdo a su credo básico a nivel estético y político, y no de acuerdo a programas arbitrariamente cambiantes y a los contenidos que apoya o formula ${ }^{21}$.

Así, la política es ontológicamente estética pero su dimensión estética en las sociedades contemporáneas ha adquirido, indudablemente, otra relevancia. Lipovetsky y Serroy sostienen que estamos en la era del capitalismo artístico o creativo transestético en el que los sistemas de producción, distribución y consumo están impregnados y modelados por operaciones de naturaleza estética. Hay una economía estética, así como una estetización de la vida cotidiana. No obstante, no dejan de reconocer que la actividad estética es una dimensión consustancial al mundo humano-social que ha atravesado diferentes fases de estetización, hasta llegar a esta cuarta etapa caracterizada por una inflación estética.

Los autores comparten en cierta medida la interpretación de Groys en términos de la extensión de la condición de artistas al conjunto de la sociedad. El capitalismo artístico ha contribuido a democratizar la ambición de crear, pero en el sentido de que todos quieren ser artistas. Aducen que todos somos artistas, proceso que ven concomitante a la trivialización del arte. A su entender, conviven la estetización hipertrofiada del mundo con la secularización del arte. Expresan: "lo que desaparece es la excepcionalidad artística aureoleada por una misión superior o supereminente: la igualdad democrática y el capitalismo transestético han logrado diluir la oposición entre creador y ciudadano corriente, entre lo 'alto' y lo 'bajo', lo artístico y lo comercial, volviendo la categoría de artista más trivial de lo que ya es (...)"22.

Groys, en cambio, considera que no sólo se ha extendido socialmente el deseo de ser artistas o el derecho a encarnar tal posición, como sostenía Joseph Beuys, sino que en las sociedades contemporáneas se produce el pasaje hacia la obligación de serlo. Insiste, además, como segundo tópico que complejiza la discusión que planteamos, que el debate sobre la estetización de la política y la politización del arte debe abandonar la perspectiva de la recepción y centrarse en la producción. Asevera:

(...) cada ciudadano del mundo contemporáneo aún tiene que asumir una responsabilidad ética, estética y política por el diseño de sí. En una

\footnotetext{
${ }^{21}$ Ibid, 34-35.

${ }^{22}$ Gilles Lipovetsky y Jean Serroy, La estetización del mundo. Vivir en la época del capitalismo artístico, Barcelona, Anagrama, 2015, 95.
} 
sociedad en la que el diseño ha ocupado el lugar de la religión, el diseño de sí se vuelve un credo. Al diseñarse a sí mismo y al entorno, uno declara de alguna manera su fe en ciertos valores, actitudes, programas e ideologías. De acuerdo con este credo, uno es juzgado por la sociedad (...). Por lo tanto, el diseño moderno pertenece no tanto a un contexto económico como a uno político. El diseño moderno ha transformado la totalidad del espacio social en un espacio de exhibición para un visitante divino ausente, en el que los individuos aparecen como artistas y como obras de arte autoproducidas ${ }^{23}$.

Para Groys es un movimiento irreversible, más aún, el problema ya no es cómo me diseño a mí mismo sino cómo me relaciono también con el modo en que el mundo me diseña. En sus términos: “(...) todo el mundo está sujeto a una evaluación estética (...). Lo que alguna vez fue un privilegio y una carga de unos pocos, en esta época de autodiseño se ha convertido en la práctica por excelencia de la cultura de masas" ${ }^{24}$. Por consiguiente, lo que predomina hoy es un arte de baja visibilidad, cotidiano y de gestos públicos débiles.

Recapitulando podemos identificar cuatro puntos de tensión en este debate, dos de los cuales hemos delineado más extensamente. El primero remite a la discusión sobre si la política es ontológicamente estética o si su estetización obedece exclusivamente a coordenadas epocales. El segundo refiere a la asociación de la estetización de la política con engaño, la seducción y la manipulación. En tercero -que no desarrollamos en su especificidad pero que se desprende del anterior- se delinea por la tensión entre concebir a la estetización de la política o a la dimensión estética de la política como algo exclusivo de la gramática del poder o como un proceso que atañe también a las resistencias. Finalmente, el cuarto tópico alude a si el proceso de estetización de la política se mira desde la la recepción, en decir, en el caso de Benjamin focalizando en cómo las masas son cooptadas o manipuladas por las estrategias del fascismo quedando la óptica de la producción limitada la politización del arte (con la que el comunismo tiene que responder a las estrategias estéticas de la política fascista). O si enfocamos también a la dimensión estética desde la óptica de la producción. En otros términos, el deber de todos de ser artistas más allá del arte, ergo, desde los gestos más nimios, débiles pero insistentes, en la estética del hacer político.

\section{Dramaturgias: las formas de aparecer en el espacio público}

\section{Piqueteros sin piquetes}

Para Chávez Mac Gregor “(...) la política es una cosa estética porque tiene que ver con apariencias" 25 . Apariencias o apariciones que entendemos en su doble sentido: como acción y efecto de aparecer y, ambivalentemente, en su alusión fabulosa, como imaginación de una

\footnotetext{
${ }^{23}$ Groys, op.cit., 33.

${ }^{24}$ Ibid, 39-40.

${ }^{25}$ Helena Chávez Mac Gregor, "Políticas de la aparición: estética y política”, en Academia.edu, 24.
} 
figura irreal, es decir, fuera del orden de enunciabilidad y visibilidad. A su entender, los nuevos movimientos sociales del siglo XXI transfiguraron el modelo de resistencia clásica de la izquierda, ya sea en la estructura de la guerrilla o del partido, hacia una nueva forma de aparición colectiva e inauguraron otras condiciones para la experimentación política. Manifiesta que: "bajo estas nuevas condiciones de la movilización, el arte puede funcionar como catalizador, (...) no como obra de arte sino como parte creativa, afectiva, comunicacional del movimiento social. (...). (...) No en tanto arte sino como parte de ese mismo cuerpo colectivo para generar un momento de socialización y aparición ${ }^{26}$.

El FPDS Rosario construyó una forma de aparecer en el espacio público en la que reivindicó elementos que provenían de la tradición piquetera. Recursos tales como pañuelos, palos y gomas fueron utilizados en sus repertorios, aunque con otros sentidos. En efecto, años atrás, en los cortes de calles, piquetes o acampes del movimiento piquetero estos elementos tenían, principalmente, fines asociados a la seguridad de las medidas. Los pañuelos cubrían los rostros de los manifestantes para evitar su identificación, los palos fueron un elemento de auto-defensa y las gomas un obstáculo para evitar la circulación de vehículos y garantizar los cortes de tránsito. Si bien este motivo utilitario fue de la mano de un sentido expresivo (para hacer resonar, por ejemplo, la estética y la ética del Ejército Zapatista de Liberación Nacional), en el FPDS Rosario, su condición de bien de uso estuvo desde el comienzo subordinada a su capacidad expresiva. Advino, entonces, una situación paradójica: la permanencia resignificada de estos elementos en momentos de repliegue de las metodologías de acción directa (como los piquetes, acampes o tomas). De este modo, los recursos se independizaron de la implementación de las acciones que les dieron origen.

Así, el FPDS Rosario construyó una dramaturgia piquetera ${ }^{27}$ a través de específicos procesos de objetivación estética que, en términos de Rancière, comprendemos como la conversión de elementos de la vida cotidiana en objetos de experiencia estética ${ }^{28}$. La trayectoria que experimentó el uso del pañuelo piquetero resulta un caso emblemático de nuestro corpus e ilustra el despliegue de esta dramaturgia.

El pañuelo es un elemento caro a la protesta social latinoamericana. Es una prenda cargada de sobrevivencias luctuosas que en Argentina encuentra su referencia más significativa en el uso que le dieron las Madres de Plaza de Mayo al portarlo en sus cabezas como signo doliente al mismo tiempo que certificado de acción política. Tal como asevera Diéguez "los pañuelos condensan las narrativas del dolor en Latinoamérica, son las escrituras del dolor, del amor, de la espera. Exagramas fantasmales. Pero también son el tejido de las Erinias, las iras de las memorias, la tenacidad de las superviviencias" ${ }^{29}$.

Como anunciábamos, en las acciones piqueteras de los años 90', el pañuelo fue utilizado por los manifestantes para preservar su identidad y para protegerse, por ejemplo, de los gases lacrimógenos utilizados por las fuerzas de seguridad. En cambio, en el FPDS

\footnotetext{
${ }^{26}$ Ibid, 30 .

${ }^{27}$ Retomamos el término dramaturgia de Jorge Dubatti quien, analizando la expresión teatral, sostiene que la dramaturgia se diferencia del drama porque no sólo focaliza en el producto sino en la acción de producción del drama, no sólo en el objeto sino en el arte de crearlos, por tanto, dramaturgia es, a su entender, "composición de dramas".

${ }^{28}$ Jacques Rancière, Sobre políticas estéticas, op.cit.

${ }^{29}$ Ileana Diéguez Caballero, Cuerpos sin duelo. Iconografías y teatralidades del dolor, Córdoba, DocumentA/Escénica Ediciones, 2013, 34 .
} 
Rosario operó como un recurso expresivo que garantizó la filiación simbólica de la organización con la tradición piquetera. Tal como pudimos constatar en los archivos fotográficos y audiovisuales, así como en los testimonios recogidos, el pañuelo fue un elemento distintivo de la indumentaria utilizada en las manifestaciones. Los mismos fueron de colores y tamaños heterogéneos (con preponderancia de los de estilo árabe ${ }^{30}$ ), se ubicaron colgados en el cuello y/o tapando parte de los rostros de los militantes.

En medidas de mayor beligerancia como los escraches, este elemento fue resaltado. Por ejemplo, en un escrache realizado el 22 de abril de 2010 a Eduardo Duhalde (presidente provisional del país al momento de la Masacre), constatamos cierta exaltación en el uso del pañuelo a partir de recrear, simbólicamente, su función de elemento de seguridad. Así, los militantes que conformaron el cordón de seguridad y contención de la medida adquirieron en esta medida una densa visibilidad dada a partir de colocarse en dos hileras, encabezando la marcha, cubriendo sus rostros con los pañuelos y portando palos que terminaron de dar forma a la expresión anhelada. Situación que difirió de otras ocasiones en las que quienes desarrollan ese rol no se distinguen tan claramente del resto de los manifestantes. De este modo, a partir de la metamorfosis de esta tarea, que suele ser rutinaria en cualquier medida de protesta, constituyeron una escena de esa dramaturgia piquetera de la que hablamos.

El pañuelo fue un recurso utilizado para insuflar un ánimo épico en los manifestantes y pretendió despertar "cierta situación de temor, de amenaza, de fuerza" 31 en quien era objeto del escrache así como en las fuerzas de seguridad dispuestas a amedrentar la acción. Una de las integrantes del FPDS Rosario, relata: "era un elemento de fortaleza, (...) en el escrache (...) hay que sentirse fuerte, y también el presentarse con una identidad piquetera generaba (...) un resguardo, como un reaseguro (...),32.

Este proceso de objetivación estética activó subjetivaciones estéticas que generaron posturas encontradas. Por subjetivación estética entendemos “(...) la diversidad imprevisible de maneras en que no importa qué individuos pueden entrar en el universo de la experiencia estética, a través de negociaciones concretas de la relación entre proximidad y distancia"33. Posturas que, pasados los primeros años en los que la dramaturgia piquetera operó en la sedimentación y cohesión colectiva necesaria para la organización naciente, alimentaron diferentes vectores de subjetivación política que entendemos como "la producción mediante una serie de actos de una instancia y una capacidad de enunciación que no eran identificables en un campo de experiencia dado, cuya identificación, por tanto, corre pareja con la nueva representación del campo de la experiencia"34.

Podemos reconstruir, a partir de los testimonios recabados, dos posiciones. Una primera que, a pesar de reconocer la continuidad que supone esta dramaturgia, destaca cierto potencial rupturista. Así algunos militantes sostienen que el pañuelo - y la forma de aparecer piquetera, en términos generales- era sinónimo de rebeldía, reponía el ideario del

\footnotetext{
${ }^{30}$ Nos referimos a la kufiya, pañuelo tradicional en Medio Oriente utilizado en distintos países árabes. Es de algodón o lino y se caracteriza por un dibujo geométrico usualmente de color negro, gris, rojo o beige sobre un fondo blanco. Su uso también se asocia a los rebeldes de esa región, principalmente a los militantes de origen palestino.

${ }^{31}$ Entrevista a militante 8.

${ }^{32}$ Idem.

${ }^{33}$ Rancière, Sobre políticas estéticas, op.cit., 72.

${ }^{34}$ Jacques Rancière, El desacuerdo. Política y filosofía, Buenos Aires, Nueva Visión, 2007, 52.
} 
movimiento y sus militantes como hijos de la rebelión popular del 2001, tanto el carácter insurrecto como la particularidad de una identificación que se monta sobre la presencia en la calle. Una de las militantes entrevistadas asevera que la construcción de esta dramaturgia piquetera significaba: "la posibilidad de (...) ser un sujeto transgresor, rebelde, que está en la calle, que quiere cambiar las cosas, que pelea, que no se queda, (...) y de alguna forma eso permaneció en el tiempo porque tenía determinada productividad en términos políticos a la hora de hacer oír algunas demandas" ${ }^{, 35}$. En este sentido, otro integrante recalca:

El tema de la estética piquetera tiene que ver con que somos los que estuvimos en el 2001, somos los hijos de esa rebelión popular, somos los compañeros de Darío y Maxi, eso sobrevivió mucho en el imaginario, en la identidad de la militancia, a la vez que se estaban dando debates políticos muy profundos que tenían que ver con reconocer que el contexto social, económico, político, era uno en el 2001 y en el 2006, era otro ${ }^{36}$.

Si bien estos militantes reconocen la necesidad de reconfigurar esa identidad piquetera acorde a los nuevos desafíos, en sus enunciaciones observamos como principal vector de subjetivación política su condición de sujetos rebeldes fieles al acontecimiento 2001. Por otra parte, distinguimos otra posición que delinea un vector de subjetivación política distinto. Esta postura subraya las persistencias y la inercia que generó esta modalidad expresiva en el espacio público. Señalan que contribuía a un proceso de fijación que obturaba la construcción de otras imágenes necesarias para acompañar un inminente momento de cambio y transformación política. Uno de los entrevistados sostiene: “era más (...) un rito, un ritual, un poco como una repetición de lo que ya venías haciendo más en términos identitarios y de cierta comodidad en lugar de lo que demandaba actualizar tu intervención política para intervenir en el momento más reciente" ${ }^{37}$.

A continuación, aclara que con el término ritual se refiere a "cuando la puesta en juego de distintos símbolos como la goma (...) no viene acompañado de una propuesta política, más actualizada para el momento vigente. (...) Para mí cuando la puesta en juego de los símbolos queda en lo ritual empieza a perder productividad política. (...) Termina siendo la muerte del símbolo, no es productivo",38. Más adelante agrega: "para mí era como la reafirmación en las definiciones, (...) significaba el estancamiento de nuestra política, la reafirmación en elementos más identitarios que no daban cuenta que teníamos que transformar y actualizar la política (...) para que Darío y Maxi no sean sólo para militantes sino para las masas" "39. Otro de los militantes entrevistados asegura: “(...) Pareciera que dar ciertos saltos (...) te podía hacer perder eso que construiste que queda como en un lugar (...) sagrado y que a veces lleva a ciertas políticas conservadoras ${ }^{40}$. Para ellos, entonces, el pañuelo y la dramaturgia piquetera significaba fijación e inercia, y, por contraposición,

\footnotetext{
${ }^{35}$ Entrevista a militante 8 .

${ }^{36}$ Entrevista a militante 3 .

${ }^{37}$ Entrevista a militante 2.

${ }^{38}$ Idem.

${ }^{39}$ Idem.

${ }^{40}$ Entrevista a militante 4.
} 
activaba el vector de una subjetivación por-venir, que reivindicaba la experimentación de la nueva etapa, una subjetividad hija, pero no aferrada al 2001.

La trayectoria del pañuelo, en los años finales de nuestro período de estudio, implicó otras operaciones acordes a este segundo vector de subjetivación. Un tránsito hacia otro uso en el que este elemento ya no aparece como certificado de la filiación a la tradición piquetera sino como dispositivo de transmisión de variadas consignas, conservando sólo en última instancia una débil reminiscencia a esa identidad. El pañuelo pasó a ser así una textura/texto. Un uso que no es privativo, aunque sí distintivo de la organización.

Los pañuelos cambiaron sus características y su ubicación. Ya no fueron más heterogéneos. sino que se homologaron cromática y morfológicamente. Fueron del mismo tamaño -más pequeños que antes-, del mismo color (por ejemplo, pañuelos rojos o verdes) y con iguales consignas impresas. Ya no cubrieron parcial o totalmente los rostros de los militantes, sino que pendieron de los cuellos, en algunos casos fueron colocados en la cabeza, puños o se convirtieron en un accesorio que ataron en sus bolsos o mochilas.

Este uso ha albergado una ambivalencia ya que el pañuelo ha sido un dispositivo de transmisión de determinadas consignas a la vez que ha desempeñado una función de makeup, de embellecimiento, de moda que no debe ser reducido a un mero carácter decorativo. Ambivalencia inerradicable ya que las motivaciones políticas y de moda remiten una a la otra y es síntoma clave de la importancia de la dimensión estética de la política en la actualidad. Como asevera Groys, sobre el uso del pañuelo en otras latitudes, “(...) decidir entre el pañuelo como símbolo islámico de convicción religiosa y como marca comercial se vuelve una tarea estética y política extremadamente difícil. El diseño no puede, por lo tanto, ser analizado exclusivamente en el contexto de una economía de la mercancía"41.

En síntesis, lo que dimos en llamar la trayectoria del pañuelo fue un proceso de objetivación estética que albergó, al menos, dos trayectos. En primer término, el pasaje desde un proceder piquetero a la construcción de una dramaturgia piquetera, a una forma de exposición que recreó la apariencia de un sujeto político en pleno proceso de repliegue de la escena política local y nacional. Operación que desató encontrados procesos de subjetivación estética y política. Primer tramo confirmado por otro en el que cada vez más se debilitó la remisión del pañuelo a la experiencia piquetera para reconfigurarse, previa transformación de su morfología, color y ubicación, en un dispositivo de transmisión de diferentes consignas, así como en un accesorio de moda militante. Esta última modulación en el uso del pañuelo tributa al proceso de carnavalización de la protesta que es el otro aspecto que configura las formas de aparición en el espacio público del FPDS Rosario y que analizaremos inmediatamente.

\section{La carnavalización de la protesta. De la presencia negra al rouge}

Para Brian Holmes y Marcelo Expósito la carnavalización de la protesta comienza entre mediados y fines de los años 90' en movimientos de resistencia de diferentes partes del mundo, conectados a su vez, entre sí. Las Street Parties de origen británico que se

\footnotetext{
${ }^{41}$ Groys, op.cit., 33.
} 
extendieron a diferentes ciudades -en las que convergieron desde las protestas ecologistas hasta parte de la tradición anarquista- y las acciones de distintos colectivos de activismo que desarrollaron prácticas festivas resultan experiencias significativas.

Sin embargo, lo que aquí nos interesa destacar no es cómo esa fiesta se apodera indiscriminadamente de la escena callejera, es decir, no nos referimos a la ética de la presencia física festiva que caracterizó el ciclo de protesta anterior, sino más bien a la conversión de esa dinámica en una premisa obligada del modo de aparecer en el espacio público de algunos movimientos sociales. Premisa que el FPDS Rosario logró materializar avanzada su vida política y no, en cambio, en los años inmediatos a su constitución, en los que por momentos acuñó una estética deprimida propia del reflujo que estaban atravesando buena parte de los espacios que lo componían. Distinguimos tres aspectos a partir del análisis de sus manifestaciones: a) la adquisición de cierta diversidad cromática, b) la redisposición de los cuerpos individuales; y c) el uso de objetos, sonidos y visualidades legados de la tradición murguera -que renació en Rosario a fines de la década del 90', junto con el reverdecer de la fiesta carnavalera en el país- ${ }^{42}$.

a) La adquisición de cierta diversidad cromática podría analizarse desde varios puntos de vista. Escogimos abordarla a partir de las transformaciones en la estética de las banderas que, por la significación que adquieren en este tipo de estructuras políticas, suelen convertirse en un punto de apertura hacia la innovación de otros símbolos organizacionales. Las banderas usadas en los primeros años y que encabezaron los repertorios de protesta contuvieron una estética dura, anquilosada. Fueron de color negro y rojo -colores que identificaban a la mayoría de las organizaciones que formaron el movimiento, como las agrupaciones Santiago Pampillón, El Grito y la CTD Aníbal Verón en Rosario-. "Éramos la presencia negra" características como la tipografía recta y la ausencia de ilustraciones terminaban de dar forma a banderas que evidenciaban una estética apesadumbrada y monótona.

Hacia el 2007 se aprecian las primeras transformaciones. Las banderas incorporan dos elementos que agrietan la imagen de los primeros años. En primer término, las tipografías se ablandan y se adhieren ilustraciones de Santillán secundado de otros militantes anónimos. Y, en segundo lugar, se incorpora la bandera argentina que corroe la tonalidad bicolor sostenida hasta el momento. Según surge de los testimonios recabados, la incorporación de símbolos de la tradición nacional fue una de las discusiones que atravesó, desde los comienzos, las decisiones sobre la estética que adoptaría la organización naciente. Uno de los militantes entrevistados asevera que desde aquel entonces la intención era desplazarse de "la estética estrictamente vinculada a la historia de la izquierda y el anarquismo. Correrte un poco del rojo y negro, como la identificación cromática básica,

\footnotetext{
${ }^{42}$ Por razones de extensión no hemos podido explayarnos en el carnaval como festividad popular y las murgas como una de sus agrupaciones festejantes principales. Para una adecuada comprensión del fenómeno resultan ineludibles los trabajos de Bajtin (1990); Eco, Ivanov y Rector (1989) y Da Matta (2002). Para su desarrollo en el contexto argentino y latinoamericano, se tornan de notoria relevancia los aportes de Martin (2009), Remedi (1996) y Cocimano (2001), entre otros. Para conocer su desarrollo en la ciudad de Rosario puede consultarse Di Filippo, Logiódice y Lucca (2013).

${ }^{43}$ Entrevista a militante 4.
} 
como única"44. La intención de ponderar nuevamente ciertos signos nacionales no sólo obedecía a la aspiración de recuperar, en otra clave, la tradición política argentina sino por el papel que la impronta nacional tuvo en la insurrección del 2001.

Hacia el año 2011 la bandera del FPDS Rosario renueva su fisonomía otra vez. Adopta una tipografía decididamente más relajada, ilustraciones en colores de los rostros de Kosteki y Santillán y otros militantes, otros símbolos del imaginario de la resistencia popular rosarina como la hormiga característica del repertorio de protesta por el asesinato de Claudio "Pocho" Lepratti ${ }^{45}$ y la bandera argentina a la que se suma una wiphala ${ }^{46}$ que, además de su referencia concreta a los pueblos originarios, reivindica cierta tradición latinoamericanista. Uno de los integrantes de la organización manifiesta lo siguiente en torno a esta última recreación del componente cromático del Frente:

Se va ganando mucho más terreno en toda la segunda mitad de la década pasada en relación también al latinoamericanismo. (...) La wiphala no era un componente estético del Frente en el 2004 como no lo era tanto la figura de Latinoamérica y de la Patria Grande. Interviene ahí toda una relectura de tradiciones políticas, de análisis de etapa, de coyuntura, de marcos de alianzas, de pensar el Estado que hace también a como se retroalimenta la forma en que vos lo expresas estéticamente ${ }^{47}$.

Se trata de un permanente ensayo de composición, de "tensión creativa"48, según asevera otro miembro del FPDS, acorde a los diferentes desafíos de articulación política que la organización iba afrontando en la construcción del espacio estético de la llamada nueva izquierda, izquierda social independiente ${ }^{49} \mathrm{o}$ "nueva izquierda autónoma"50.

En efecto, para una de las militantes las banderas cumplieron un importante rol de síntesis simbólica de la heterogeneidad que albergaba la organización ${ }^{51}$. Una síntesis paradójica puesto que avanzó progresivamente hacia una diversidad cromática que no fue, sin embargo, dispersión sino una heterogeneidad homogeneizante, es decir, la inclusión de nuevos colores que permitió alcanzar la síntesis necesaria para contener el variopinto conjunto de tradiciones políticas, discursivas y estéticas puestas en juego. De este modo, la diversificación cromática potenció una de las características distintivas del Frente como nueva subjetividad política colectiva: su carácter multisectorial, su vocación articuladora.

\footnotetext{
${ }^{44}$ Idem.

${ }^{45}$ Claudio "Pocho" Lepratti fue un militante social asesinado, en Rosario, por la policía de la Provincia de Santa Fe, el 19 de diciembre del 2001. Su asesinato desató un proceso de lucha y un repertorio de protesta que fue decisivo en la conformación de la gramática de la protesta social rosarina de las últimas décadas.

${ }^{46}$ Wiphala es el nombre con el que se designa a las banderas cuadrangulares de siete colores utilizadas por diferentes etnias, principalmente, de la región de los Andes. El término es de origen aimara y significa 'emblema'.

${ }^{47}$ Entrevista a militante 4.

${ }^{48}$ Entrevista a militante 2.

${ }^{49}$ Entrevista a militante 3.

50 Mariano Pacheco, De Cutral-có a puente Pueyrredón. Una genealogía de los Movimientos de Trabajadores Desocupados, Buenos Aires, Ed. El Colectivo, 2010, 294

${ }^{51}$ Entrevista a militante 5.
} 
b) En segundo término, mencionábamos la re-disposición de los cuerpos individuales y/o del cuerpo propio como otro rasgo distintivo. Con este aspecto referimos a una disposición de los cuerpos a ser intervenidos. Al igual que en el punto anterior, podríamos mencionar varias iniciativas, pero nos interesa hacer hincapié en la tendencia a que los cuerpos sean pintados y/o lo sea su indumentaria.

Los militantes del FPDS marcharon en reiteradas ocasiones con los rostros pintados. Por ejemplo, en una intervención realizada por la segunda desaparición de Jorge Julio López $^{52}$ en la que se pintaron de color blanco con un signo de pregunta en negro. También se inscribieron en los rostros coloridas consignas o dibujos, sobre todo, en las marchas del movimiento de mujeres en las que además fue habitual que marcharan con los labios pintados. Al respecto, una de las integrantes de la organización asevera:

Siempre (...) nos gustó mucho pintarnos la cara, (...) romper un poco con esta idea más clásica de que la izquierda es seria, y que seria significa aburrida. (...) Vos podés ser una organización (...) coherente y que tu marcha sea un carnaval (...) poder interpelar desde otro lugar o convocar a otros. Esto que nos canta el Partido Obrero "quieren hacer la revolución con estudiantes y malabaristas" ${ }^{\text {53 }}$.

Asimismo, la indumentaria fue intervenida. Los militantes vistieron accesorios como los pañuelos de colores a los que antes referimos -lisos o con consignas- consignas que también fueron estampadas en remeras. Además, en acciones alusivas a problemáticas de género, los varones marcharon luciendo polleras.

Esta re-disposición del cuerpo propio implica rebatir al cuerpo como superficie de dolor, padecimiento o sacrificio en favor de una puesta del cuerpo en la que se destaca su capacidad de engendrar placer. Cuerpos que se posicionan en el espacio público como cuerpos cálidos, carnosos, en un claro gesto de "erotización de la militancia"54. Se reponen así en la calle cuerpos celebratorios, cuyo ánimo los devela en su intimidad, es decir, los vuelve cuerpos próximos, tocables, palpables.

Así las cosas, queremos detenernos en la razón por la que insistimos en señalar una re-disposición del propio cuerpo, sin hacer extensiva esta apreciación al cuerpo colectivo que se vertebra en las manifestaciones del movimiento. Este señalamiento evidencia las tensiones entre las dinámicas carnavaleras y las sentidas persistencias de algunas disposiciones clásicas de las organizaciones políticas que reponen escenificaciones de la militancia de décadas anteriores. En efecto, en los documentos fotográficos y audiovisuales

\footnotetext{
52 Jorge Julio López fue un albañil y militante del peronismo de izquierda en barrio Los Hornos en la periferia de La Plata, secuestrado y desaparecido durante la última dictadura militar, entre los años 1976 y 1978. López sobrevivió al terrorismo y fue testigo en los Juicio por la Verdad por los delitos de lesa humanidad cometidos durante la dictadura. Involucró a más de sesenta militares y policías y su testimonio fue clave para condenar a Miguel Etchecolatz, otrora Director de Investigaciones de la Policía Bonaerense y mano derecha del ex-general Ramón Camps de la policía de la provincia de Buenos Aires. El 18 de septiembre de 2006 poco después de declarar y cuando aún se desarrollaba el juicio en el que había testificado, Jorge Julio López volvió a desaparecer cuando se dirigía desde su casa en Los Hornos hacia el juzgado en clara represalia por su declaración. Aún permanece desaparecido.

${ }^{53}$ Entrevista a militante 5.

${ }^{54}$ Entrevista a militante 4.
} 
y en las observaciones realizadas, advertimos que la organización conserva el modo de composición en columnas, encabezadas por banderas y con un tránsito guiado por el ritmo que marcan las primeras hileras de militantes. Por tanto, se sostiene implícitamente el precepto de homogeneidad manifestante. Ergo, al decir de Expósito, parece permanecer:

El viejo imaginario izquierdista de una mítica unidad opositora con un objetivo principal que subsume el resto de las formas de antagonismo consideradas secundarias -en la izquierda clásica, se trata de la subsunción de toda conflictualidad social a la contradicción central entre capital y trabajo que encarna el sujeto político unitario representado en la tradicional manifestación lineal, donde una masa homogénea recorre un mismo camino entre un punto de inicio y un punto de llegada ${ }^{55}$.

Es decir, los cuerpos individuales de los manifestantes adquirieron un ánimo carnavalesco que los dotó de una fluidez, una movilidad que, no obstante, se obtura cuando componen el cuerpo colectivo manifestante, el gigante vertebrado, esa una suerte de procesión sólida. En síntesis, la disposición orgánica, la morfología manifestante con su forma de desplazamiento rígida, se fisuró sólo parcialmente a partir de estos cuerpos coloridos. Señalamiento que nos conduce al último aspecto que destacamos como clave para pensar este proceso de carnavalización de la protesta.

c) Marcábamos como tercer elemento la utilización de objetos, sonidos y visualidades propias de la tradición murguera. Al respecto, nos interesa señalar la presencia de objetos de grandes dimensiones, como cabezudos, que se constituyeron en elementos típicos de los escraches, así como también de los actos en conmemoración de la Masacre de Avellaneda en donde, por lo general, fueron incinerados. También compusieron las escenas de los llamados juicios populares en los que se parodiaba la realización de un juicio por parte de la población civil a los responsables de la Masacre. Estos muñecos de grandes dimensiones remiten necesariamente a dos antecedentes. Por una parte, fueron utilizados en las puestas de los colectivos de activismo artístico distintivos del ciclo de protesta anterior $\mathrm{y}$, por otra, son distintivos de las carnestolendas, sobre todo por la figura del Momo. A ello debemos adicionar el transitar de esos cuerpos marchando al ritmo de instrumentos de percusión, con expresiones propias de la corporalidad murguera e incluso con arengas y presencia de integrantes de murgas. Así, el estilo del desplazamiento murguero, además de la presencia ocasional de estas agrupaciones y la acción de pintarse los rostros, que también remite a dicha tradición, aportaron otras aristas a este devenir carnavalesco de la protesta.

La carnavalización y la alegría como estrategia política ${ }^{56}$ fue una característica distintiva del FPDS. De tal modo que uno de los entrevistados sostiene que: "cuando no se percibe esa alegría, esa convicción, para mí es como un correlato de los problemas que estás teniendo como organización, las formas de procesarlos y la falta de convicción de

\footnotetext{
55 Marcelo Expósito, "Desobediencia: la hipótesis imaginativa”, en Jesús Carrillo y Juan Antonio Ramírez, (eds.), Tendencias del arte. Arte de tendencias, Madrid, Cátedra, 2004, 8.

${ }^{56}$ Roberto Jacoby, “La alegría como estrategia”, Zona erógena, № 43, Buenos Aires, 2000.
} 
dónde estás parado. En otras organizaciones no pensás en ese correlato"57. Luego suma: “en el Frente es (...) clave y hasta se transforma en una cierta unidad de medida. (...) Llevar las pancartas de colores, pintarse los labios o pensar acciones (...) (para) expresar la alegría que nos significa estar marchando (...) Cómo pensamos que no es un sacrificio, una cosa altruista, de abnegado sino como expresar la alegría de estar organizado" ${ }^{\text {. }}$.

Esta apariencia carnavalera cuestionó las formas de visibilidad de la militancia en décadas anteriores. Uno de los militantes entrevistados relata al respecto:

(...) hay una reivindicación muy fuerte de la dimensión de la alegría, de luchar con alegría. (...). En buena parte de este tipo de movimientos, de colectivos, que surgen después del 2001 hay una impronta muy fuerte de cuestionamiento a las formas de hacer política de los partidos, a esa forma más acartonada del lenguaje y a las formas de interpelación, los sujetos a convocar, siempre lo hacían desde un lugar más ideologizado. En cambio estos movimientos hacen una reivindicación desde lo cultural, a la hora de presentarse tanto en las marchas como en el territorio $(\ldots)^{59}$.

Más adelante, sostiene:

Poder hacer las cosas con alegría (...) generaba un sentido de pertenencia, formar parte de un colectivo, sobre todo en un momento de reflujo, de estigmatización de la protesta, de normalización institucional y de la política, hacían falta esos rituales de construcción de identidad para poder hacer política en un contexto más hostil que un par de años previos ${ }^{60}$.

A continuación, otro de los integrantes insiste en el componente generacional de esta estrategia de la alegría puesto que agrietaba los imaginarios sobre los que se construyeron los modos de hacer política. En sus palabras: "la recuperación de las historias de la militancia de los 70' tiene mucho que ver con el sacrificio y con el lugar del mártir. (...) No se puede escindir eso del contexto en el que se estaba, pero no siempre se lo problematiza en el marco del contexto sino que se lo pensaba desde un lugar de virtud, la abnegación y el sacrifico y el 'dejo la vida por la causa",61. La ruptura con ese legado que el proceso de carnavalización de la protesta desató queda evidenciado con claridad en la anécdota que comparte otra de las entrevistadas. Sostiene:

En los diez años, estábamos en la vigilia de la Masacre, enfrente de la yuta $^{62}$. A las doce se sube al puente, se agita un poco a la yuta y se baja para subir al otro día. Y había un compañero histórico de Lanús que se da vuelta y dice "pensar que yo en el 2002 estaba acá, todo encapuchado con

\footnotetext{
${ }^{57}$ Entrevista a militante 4.

${ }^{58}$ Idem.

${ }^{59}$ Entrevista a militante 3.

${ }^{60}$ Idem.

${ }^{61}$ Idem.

${ }^{62}$ La palabra "yuta” es un término del léxico lunfardo utilizado para referir al personal policial.
} 
palos, cagándome a palos y ahora estoy con un bombo haciendo murga enfrente de la yuta" ${ }^{\prime 63}$.

Empero, si bien la idea rectora "que la tristeza no sea nunca unida a nuestro nombre" $" 64$ guió buena parte de las comparecencias ${ }^{65}$ del FPDS Rosario en el espacio público, convivió con el mito fundacional de la organización, a saber: el asesinato de Kosteki y Santillán y los modos en que la figura de este último fue recuperada en la dramaturgia piquetera y en las prácticas místicas de las que nos ocuparemos en lo inmediato.

En efecto, esta organización, como buena parte de los movimientos sociales populares, se fundó sobre la figura de un mártir, en este caso, de Darío -joven, solidario, valiente, comprometido- que entregó la vida por intentar salvar la de su compañero herido (Kosteki). Y es aquí donde se delinea un aparente dilema entre este mito fundacional que, además, es reivindicado en la dramaturgia piquetera, y las dinámicas de carnavalización de la protesta. Más que tensión emerge la ambivalencia entre la fiesta y el mártir. Aparente dilema en tanto estas apuestas en los modos de aparecer no sólo son formas de recrear la escenificación de la militancia sino umbrales en un desafío más importante que supone alumbrar "nuevas figuras del compromiso"66 que se desplacen de las imágenes clásicas. Ensayos en el camino de "inventar una nueva disciplina feliz", como asevera Holmes ${ }^{67}$.

\section{La mística. San Darío del Andén}

La idea de mística remite al campo de interacciones entre religión y política. Más específicamente, a las formas en que prácticas e imaginarios de índole religiosa, en el sentido de un re-ligare político y social forman parte constitutiva de la política. En este caso, nos ocuparemos, como parte de la dimensión estética de la política del FPDS Rosario, de prácticas que pueden inscribirse en el campo de la religión en un sentido amplio pero que no son privativas de éste. Éstas componen una pequeña muestra de la infinidad de instantes íntimos, pero inmediatamente colectivos que suscitan y modulan buena parte de los afectos que se despliegan con mayor visibilidad en las acciones públicas callejeras. De hecho, pensada en estos términos, la mística se vuelve inasible ya que su consideración podría extenderse a una multiplicidad de momentos que configuran una esfera más generalizada y difusa a la vez que omnipresente. En efecto, desde la organización expresan:

Reconocemos dos tipos de mística, aquella que se da en la cotidianeidad (en una marcha, en una asamblea) y aquella que fue pensada y organizada con anticipación para realizarse en un momento determinado. Nuestra mística busca generar confianza, ir deconstruyendo el individualismo,

\footnotetext{
${ }^{63}$ Entrevista a militante 6.

${ }^{64}$ Entrevista a militante 1.

${ }^{65}$ Didi-Huberman, op.cit. pág. 104. Para Didi-Huberman la comparecencia es la exposición colectiva de la comunidad.

${ }^{66}$ Expósito, op.cit., 5.

${ }^{67}$ Ana Longoni, Daniela Lucena y Julia Risler, "Entrevista colectiva a Brian Holmes en Buenos Aires”, Ramona, Buenos Aires, $\mathrm{N}^{\circ}$ 55, 16.
} 
generando un sentimiento de unidad. Y este proceso se da en el accionar cotidiano, lo hacemos todxs, en la práctica y en los diferentes espacios; hace al bienestar común, busca dar cuenta de nuestra construcción, expresarnos y motivarnos a seguir construyendo" ${ }^{168}$.

La mística en sus términos más acotados, remite a instancias organizadas, a un conjunto de acciones que desde el FPDS reconocen legadas del Movimento dos Trabalhadores Rurais Sem Terra (MST), movimiento para el que la mística es "parte esencial de su simbolismo organizativo y metafóricamente equiparable al corazón del movimiento"69. La definen como una energía vital ${ }^{70}$. En efecto, tal como sostiene Vallverdú, para el MST la mística es parte fundamental de sus mecanismos organizativos y normativos de motivación, compromiso y construcción identitaria.

Según expresan en el Cuaderno de Formación N²4 del MST, la mística se destina a reivindicar y fomentar una serie de valores (entre los que mencionan: humildad, honestidad, coherencia, convicción, perseverancia, pasión, amor por la causa, espíritu de sacrificio, responsabilidad y disciplina), debe contener los símbolos organizativos (banderas, consignas, cantos, himnos, etc.), reivindicar la memoria histórica popular, la práctica cotidiana del movimiento, los objetivos de lucha y sus utopías así como los procesos de lucha vivenciados hasta el momento.

Reconstruyendo sus características Vallvardú destaca que "tiene una dimensión sacra, iniciática, experiencial y sacrificial. Significa comunión de fe y esperanza en todo lo que une, inspira confianza y da fuerzas para luchar. Posee asimismo un componente estético y es una noción sinónima de evento festivo y efervescente",71. En suma, la mística se encarna en diferentes prácticas organizadas de tipo celebratorias, recala en variados recursos expresivos y posee un indudable componente estético y un cariz festivo.

Las prácticas místicas que encarnó el FPDS Rosario pueden dividirse entre aquellas desarrolladas al interior de la organización en diferentes instancias como reuniones, plenarios, campamentos, espacios de formación, fiestas internas, etc. así como otras desplegadas en congregaciones abiertas como encuentros o fiestas de las que formaron parte personas no pertenecientes a la organización. Por lo demás, si bien el espacio callejero no es el lugar de emplazamiento de las místicas, en algunas ocasiones se ha dado este nombre a momentos previos a la concreción de medidas de fuerza, lo que las vincula a la carnavalización de la protesta. A excepción de estas últimas que revisten un carácter más espontáneo, todas han sido pensadas y planificadas previamente.

En términos generales, las místicas consistieron en instancias celebratorias en torno a un tópico particular. Según relatan los entrevistados y tal como pudimos constatar en las

\footnotetext{
${ }^{68}$ Espacio de Cultura del FPDS, "Documento del $4^{\circ}$ Plenario Nacional de Cultura", Buenos Aires, 2013, 13.

${ }^{69}$ Jaume Vallverdú, "Símbolos religiosos y acción colectiva: la 'mística' del movimiento de los trabajadores Rurales sin tierra (MST) de Brasil”, en Mónica Cornejo, Manuela Cantón. y Ruy Llera Blanes (eds.), Teorías y prácticas emergentes en antropología de la religión, Donostia-San Sebastián, ANKULEGI antropologia elkartea, Federación de Asociaciones de Antropología del Estado Español, 2008, 296.

${ }^{70}$ Movimento dos Trabalhadores Rurais Sem Terra, "Método de trabajo popular. Cuaderno de formación N $\mathrm{N}^{\mathrm{o}} 24$ ", São Paulo, CONCRAB/MST, 2004, 27.

${ }^{71}$ Vallvardú, op.cit., 298.
} 
ocasiones en las que hemos participado, predominaron las denominadas místicas piqueteras, en consonancia con sus modos de aparecer en el espacio público, ya sea a través de rememorar a sus mártires o de revivir acontecimientos íconos. En otras, en cambio, se recuperaron otros procesos de lucha argentinos o latinoamericanos (el de los campesinos sin tierra en Brasil, el zapatismo mexicano, o la militancia argentina de los años setenta) así como las figuras de otros militantes o líderes políticos (desde Ernesto "Che" Guevara y Eva Perón hasta Pocho Lepratti).

En reiteradas ocasiones consistieron en representaciones teatrales o acciones performáticas que incluyeron elementos como fuego, pancartas, banderas, objetos de grandes dimensiones, etc. interpretadas por los militantes que asumían su organización, con un momento posterior del que participaban todos. En otras, en cambio, no se produjeron situaciones escénicas actor/espectador sino acciones que integraron desde el comienzo a todos los presentes.

Tanto por los recursos expresivos utilizados como por las acciones desarrolladas en su transcurso, generalmente de tipo teatrales o performáticas, estas prácticas contuvieron una fuerte impronta estética e incluso artística. Pero no nos interesa pensarlas en este sentido, sino más bien reflexionar sobre cómo la mística compone, junto con los modos de aparecer en el espacio público, otro aspecto de la dimensión estética de la política.

Cuando analizábamos las formas de aparecer en el espacio público sosteníamos que formaban parte de la dimensión estética de la política en tanto eran apariciones que interpelaban y daban forma a las configuraciones de lo sensible, que establecen lo que es visible y enunciable. En otros términos, operaban fundamentalmente en el régimen de la visibilidad y enunciabilidad. A diferencia de ello, consideramos que las prácticas místicas deben ser pensadas como un aspecto más de esta dimensión estética de la política en tanto remiten directamente a otro punto de la configuración de lo sensible, sin más: el orden del afecto. Si bien los modos de aparecer también repercuten indudablemente en este orden, las prácticas místicas maquinan privilegiadamente en este terreno en tanto constituyen dinámicas de interacción al interior de la organización que buscan generar efectos de movilización afectiva a través de auspiciar intensos espacios de encuentro ${ }^{72}$.

Ahora bien, es innegable el carácter representativo, figurativo, en palabras de Deleuze $^{73}$, en el que recaen estas prácticas. En efecto, se construyen imágenes pedagógicas representativas (de procesos políticos, luchas, militantes, etc.) y auto-representativas. Más aún, a partir de los testimonios evidenciamos que la simbolización posterior de lo que sucede a nivel sensitivo, connota cierto aprisionamiento en el código del lenguaje organizativo, lo que dificulta incluso recuperar otras resonancias sensibles. Por consiguiente, la mística tensiona, utilizando los términos de Deleuze, la lógica de la sensación con la producción de sentimiento que consiste en una elaboración discursiva a partir de determinada afectación sensible. Es una forma de representar y expresar desde el sentido lo vivido por la experimentación de una sensación. Sensaciones que para Deleuze, en cambio, son pura fuga del sentido, no porque no puedan representarse sino porque su

\footnotetext{
${ }^{72}$ Noelia Figueroa, “Acerca de piquetes y otras místicas populares”, escrito inédito, 2011.

${ }^{73}$ Gilles Deleuze, Francis Bacon. Lógica de la sensación, Madrid, Arena Libros, 2009.
} 
vivencia excede la posibilidad de aprehensión por parte de las categorías representacionales vigentes $\mathrm{y}$, en todo caso, obliga a generar otras nuevas.

La conversión de la producción maquínica de sensaciones (de perceptos y afectos) en sentimientos, podemos rastrearla en los modos en que desde la organización sintetizan las posturas que tienen respecto de la praxis mística. Sostienen:

Necesitamos ritualizar para revalorizar la construcción colectiva, romper con la cotidianeidad, visibilizar lo invisible por ser cotidiano y usual. Reafirmar el sentimiento mutuo, reavivar procesos, motivarnos, contribuir a la paciencia al hacernos sentir hoy aquello que a veces parece lejano, reafirmar esa sensación de que el/la compañerx está disponible y es alguien en quien podemos confiar.

Algunxs encuentran su motivación o su horizonte en la religión, nosotrxs también tenemos fe, creemos en que organizadxs vamos a poder transformar la sociedad, estamos convencidxs de que creando poder popular avanzaremos en la construcción de una sociedad justa e igualitaria, donde no haya pobreza, hambre ni explotación ${ }^{74}$.

La mística parece ser, entonces, principalmente, producción de sentimiento de fe. Reanudación de la fe. Una de las militantes manifiesta: "la mística tiene que ver con la fe, con creer en eso que no está tan visible, tan palpable (...) Es como ese aspecto más religioso (...). Es un poco lo que marca el horizonte. Lo que te genera la posibilidad de futuro y que puede ser mejor" ${ }^{27}$. En palabras de otra de las integrantes de la organización: "la mística tiene que ver con esa posibilidad de articular diferentes temporalidades en relación a algo que pasó y a algo que vos querés construir. Y tiene que ver con pensar las relaciones más prefigurativas de la práctica, ensayar algunas cosas que tienen que ver con cómo nos imaginamos la sociedad emancipada"76.

La mística reanuda la fe en el movimiento y en el proyecto político. Paralelamente, activa la potencia sensible de lo colectivo, del afecto-en-común. Refiere a la "posibilidad de actuar juntos desde algo sentido, desde aquello que nos afecta, desde nuevas formas de simpatía y solidaridad",77, donde se performa cierta inteligencia corporal colectiva. Como asevera otra de las militantes entrevistadas:

Para mí es más una búsqueda que otra cosa, en términos de la constitución de una identidad colectiva. (...) Me parece que tiene un potencial y como una cuestión hasta más espiritual de construcción de un nosotros ante otro que no queremos ser y que queremos combatir. (...) Para mí es fundamental, sin mística, sin prefigurar otro tipo de sociedad, la militancia

\footnotetext{
${ }^{74}$ Espacio de Cultura del FPDS, op.cit., 14.

${ }^{75}$ Entrevista a militante 7.

${ }^{76}$ Entrevista a militante 5 .

77 Javier Gil, "De luces y sombras: a propósito de las estéticas comunitarias y colaborativas", Errata. Revista de Artes Visuales, N7, Bogotá, 2012, 125.
} 
se volvería algo totalmente alienante. Por eso tiene que seguir siendo una apuesta a profundizar en la nueva organización que estamos haciendo ${ }^{78}$.

En los testimonios se insiste en la experimentación sensible colectiva, en la comunión que propicia la mística, que es, sin dudas, una interacción estética, ergo, "un vínculo en donde el afectar y el dejarse afectar definen la postura existencial con el otro"79. Ahora bien, ¿qué tipo de comunión sensible se actualiza en estas instancias?

Advertíamos en los párrafos iniciales de este apartado que las místicas, preferentemente, han sido de estirpe piquetera. En efecto, la muerte de Santillán fue una de las temáticas más tratadas. En este sentido, el abordaje de las muertes propias es la posibilidad de ejercicio de un duelo colectivo ${ }^{80}$. Las místicas son "poéticas del duelo"81 que motivan vibraciones comunitarias, ya que inauguran la posibilidad de una comunidad -la comunidad de dolientes- que transforma esa experiencia de dolor con los demás en vínculo forjado y en una experimentación inmediatamente política.

En las místicas hay luto: se recuerda a los muertos, se cuentan sus historias cotidianas, se celebra su vida rememorando sus acciones, se corean sus nombres y se entonan cánticos que celebran lo que han hecho en vida. Además de la rememoración, se los heroiza, se los canoniza, se los santifica. La figura de Darío Santillán se convirtió así en San Darío del Andén. Un personaje cuya imagen distintiva, que ilustró buena parte de este proceso de mistificación, emula a Cristo. En la imagen se muestra a Darío con los brazos abiertos en forma de cruz y con el corazón irradiando luz y proviene de una fotografía en la que el joven militante es retratado sonriendo, con los brazos abiertos, en medio de un piquete $^{82}$.

Dentro de los estudios sobre canonización de los muertos populares, Carozzi indica que en la década del 90' se produjo en Argentina una nueva ola de canonizaciones, entre las que cita los casos de músicos populares como Rodrigo Bueno o Gilda, el caso de María Soledad Morales o el impulso que toma la figura del Gauchito Gil ${ }^{83}$. Según indica la autora, la muerte joven y violenta funciona como un factor determinante en la canonización, cuestión que corrobora a partir de los testimonios detallados sobre el hecho puntual de la muerte y el hincapié que los deudos hacen en las características asociadas a la juventud de la víctima. Esta situación se repite en el caso de Darío Santillán. Su juventud y una serie de

\footnotetext{
${ }^{78}$ Entrevista a militante 6.

${ }^{79}$ Gil, op.cit.

${ }^{80}$ Figueroa, op.cit.

${ }^{81}$ Víctor Vich, Poéticas del Duelo. Ensayos Sobre Arte, Memoria y Violencia Política en el Perú, Lima, Instituto de Estudios Peruanos, 2015.

${ }^{82}$ La imagen inicial fue tallada y pintada en la Estación Avellaneda. Se compone de la figura de Santillán con una plegaria que reza: "San Darío del Andén sin sotanas ni uniformes luchaste por trabajo, dignidad y cambio social. Héroe y mártir, piquetero. San Darío San-Tillán”. Esta intervención tiene la particularidad de garantizar su reproducción en tanto si se apoya tinta y un papel, tela u otro material, puede ser fácilmente duplicada. Se constituye en una intervención cuya generosidad se liga con una de las características más destacadas de Santillán (su solidaridad). Esta imagen ha sido luego reproducida en diferentes formatos, tamaños y soportes.

${ }^{83}$ María Julia Carozzi, “Antiguos difuntos y difuntos nuevos. Las canonizaciones populares en la década del 90”, en Daniel Míguez, y Pablo Semán (eds.), Entre santos, cumbias y piquetes: las culturas populares de la Argentina reciente, Buenos Aires, Biblos, 2006.
} 
rasgos vinculados a su perfil de joven militante fueron las virtudes sobre las que se construyó buena parte de la narrativa que se cristalizó en las místicas.

Carozzi agrega que a la muerte violenta joven suele sumarse el horror por el cuerpo muerto fuera de lugar, al que no se le tributan los respetos o los tratos que merecen los difuntos, sobre todo en el caso de los cuerpos que han sido mutilados o maltratados luego de su deceso. Aquí también encontramos otra correspondencia con lo sucedido en el caso de Santillán. La crueldad con la que personal policial trata a Darío herido, agonizante y muerto, circulan tanto en los relatos orales como en documentos audiovisuales y fotográficos que forman parte de los materiales que componen estas instancias. Las famosas imágenes del Comisario de la Policía Federal Argentina, Alfredo Franchiotti y sus subordinados, levantando a Darío y volviéndolo a largar contra el piso, arrastrándolo y cargándolo en una camioneta fueron escenas que conformaron el imaginario que permitió la elaboración del duelo colectivo.

Según algunas interpretaciones, estos procesos de canonización se ligan a cierta vocación de venganza o revancha de sectores sociales vulnerados. Incluso en la adjudicación de milagros a estos santos populares los autores advierten una de sus formas de resistencia. De Certeau sostiene al respecto:

Una inaceptabilidad del orden social ya instalado se expresaba, con justa razón, bajo la forma del milagro. Allí, en un lenguaje necesariamente ajeno al análisis de las relaciones socioeconómicas, podía mantenerse la esperanza de que el vencido de la historia -cuerpo sobre el cual se escriben continuamente las victorias de los ricos o de sus aliados- pueda, en la "persona" del "santo" humillado, ponerse en pie gracias a las buenas pasadas que el cielo puso en juego contra sus adversarios ${ }^{84}$.

A diferencia de lo que describe De Certeau, a Darío Santillán no se le atribuye la concreción de milagros ni es habitual que sus deudos o fieles le realicen pedidos. A excepción de un altar que una devota construyó en la Estación Avellaneda -renombrada como Estación Darío y Maxi-, el vínculo entre vivos y muertos o entre la vida y la muerte se traza de otro modo. Se configura a partir de la reactualización de un destino común, es decir, el duelo colectivo se vehiculiza a través del imperativo de continuar la lucha de los muertos en un presente que, a su vez, porta una fuerte impronta prefigurativa de un futuro que se delinea colectivamente. Ahí, en ese gesto, hay alivio, hay transformación, hay vida. Vida que se gestiona en la obligación de recordarlos con alegría. Tal como asevera Figueroa, investigadora y militante del FPDS, "la recuperación (...) es selectiva, y hace hincapié en la posibilidad de justicia (a Darío y a Maxi los vamos a vengar, con la lucha popular, reza uno de los cantos recurrentes) con la continuidad de la lucha en alegría"85.

Queda de manifiesto, entonces, la tensión entre las dos condiciones asociadas a la figura de Santillán: la de militante y la de santo. Darío es santificado como piquetero. En las imágenes que se utilizan en las prácticas místicas, que operan como dispositivos de

\footnotetext{
${ }^{84}$ Michel De Certeau, The Practice of Everyday Life, Berkeley, University of California Press, 1984, 21.

${ }^{85}$ Figueroa, op.cit.
} 
santificación, Darío aparece siempre acompañado de los recursos expresivos distintivos de la lucha piquetera (pañuelos, palos o gomas) o con su mano extendida en ese último gesto de entrega que le costó la vida. Asimismo, el rezo que acompaña la imagen de Santillán da cuenta de esta complejidad como así también el hecho de que en su nombre de santo ("San Darío del Andén") se destaque una fuerte territorialidad política: la estación del piquete (también de su muerte) que reafirma su identificación militante.

Darío, entonces, es un santo luchador, hereje. En efecto, mientras que a los santos se les pide (deseos, ayuda, consejos), a Darío se lo santifica para rememorarlo, pero se le es fiel continuando con su lucha. Es un santo que incita a la acción, no promueve la pasividad de quien recibe un milagro, es un santo que demanda y al que no se le demanda. Así la lógica de la promesa se invierte: no hay pedido a cambio del cual se promete el cumplimiento de una acción, que generalmente trae aparejado un sufrimiento del deudo que de algún modo paga o compensa el milagro recibido, sino que el santo se politiza y la promesa adquiere la morfología de la promesa política. La promesa como estructura de la política emancipadora, de la sociedad por-venir.

\section{Conclusiones}

Nos interesa aquí recuperar la cartografía de tensiones que delineamos en las páginas iniciales en relación a los debates sobre la dimensión estética de la política en los cuatro tópicos que distinguimos (la política ontológica o históricamente estética; la estetización asociada a la manipulación y al engaño; la estética de la política como una dimensión exclusiva de la gramática del poder o también de las resistencias; y el énfasis puesto en la producción o en la recepción); así como nuestra hipótesis de trabajo para así esbozar algunas líneas finales. Líneas que marcarán, desde los alcances y límites de nuestra experiencia de investigación, zonas de concordancia y discordancia, siempre dispuestas a tomar otros contornos en función de nuevas búsquedas y aperturas.

En primer término, tal como hemos evidenciado a lo largo de nuestro análisis de movimientos sociales como el FPDS Rosario, éstos experimentaron a partir de la segunda mitad de la década del 2000 un intenso trabajo sobre la dimensión estética de su política, recreando sus modos de aparecer en el espacio público y enriqueciendo su esfera mística.

En este sentido, si bien coincidimos con Rancière en que la política es ontológicamente estética, postulamos que en las coordenadas históricas actuales dicha dimensión cobró una notable relevancia siendo una característica fundamental de la política del tipo de movimientos que surgieron en este ciclo de protesta y por ello coincidimos en la pertinencia de atender a los arduos procesos de producción de estas escenificaciones.

Por consiguiente, disentimos con la afirmación de que la estetización sea una característica repudiable de la política o asimilable a intenciones de manipulación y engaño. Consideramos que, tal como hemos visto en lo que atañe a la dramaturgia piquetera, a los modos de carnavalización de la protesta y a las acciones que compusieron la dimensión mística del FPDS Rosario, esa manufactura estética fue vital para afrontar un escenario en el que los viejos modos de aparecer habían perdido sentidamente legitimidad e incluso posibilidades de visibilidad y enunciabilidad. 
En efecto, reconociendo que no es una problemática exclusiva del poder, sino que es un aspecto clave de las gramáticas de las resistencias, a partir de los relatos que hemos recuperado de los militantes, de los documentos consultados, así como en base a nuestras observaciones consideramos que la recreación de dicha dimensión contribuyó al desarrollo del proceso de subjetivación política colectiva de la organización naciente.

Los entrevistados cuando aluden a la reposición y recreación de ciertos elementos simbólicos de la lucha piquetera, lo que denominamos la constitución de la dramaturgia piquetera, destacan el componente identitario, en nuestros términos los modos en que incitó subjetivaciones políticas. Delineó, fundamentalmente, una figura posible de lo colectivo al estimular cierta unidad en un momento de dispersión y heterogeneidad dado el momento embrionario en el que se encontraba la organización producto de la fusión de otras que provenían de tradiciones diferentes. La dramaturgia piquetera fue un factor de cohesión indispensable que desató, luego, vectores de subjetivación encontrados, entre quienes resaltaban su fidelidad al acontecimiento 2001 y quienes reconocían este origen pero demandaban una nueva subjetividad acorde a los nuevos tiempos.

Por otra parte, la carnavalización de la protesta, según los relatos y observaciones que recogimos, fueron prácticas constitutivas de su condición de militantes de la nueva organización, que generaron sentido de pertenencia generacional. El festejar la lucha y la estrategia política de la alegría fue una característica distintiva que diferenció al movimiento y a sus integrantes de otras organizaciones de izquierda al romper, no sin tensiones y ambivalencias, la estética sacrificial de la militancia de décadas anteriores. Incluso adoptó un carácter prefigurativo de la sociedad anhelada.

Finalmente, las prácticas místicas también aportaron en la construcción de esa subjetividad colectiva. Las místicas fueron instancias eminentemente afectivas, celebratorias, de revitalización, de reanudación de la fe. Prácticas que operaron en la configuración de una comunidad de dolientes y en la politización del dolor puesto que, a diferencia de buena parte de los mártires populares, aquí no hubo ruegos ni pedidos pasivos, sino la reactualización de un destino común. Es decir, poéticas del duelo que transformaron el dolor e instauraron el imperativo de continuar la lucha en un presente que, a su vez, porta una fuerte impronta del futuro que se delinea colectivamente. Ahí, en ese gesto, se cristaliza la obligación de militar con alegría y se actualizan las figuras del compromiso político, proceso que se nutre de la carnavalización de la protesta que renueva, ambiguamente, las imágenes y posturas sacrificiales clásicas de la militancia.

Fue entonces en el sistema de producción de estéticas cotidianas, en la fabricación de esos modos de aparecer en el espacio público donde se desplegaron instancias de consolidación en una subjetivación colectiva que se construyó, por supuesto, de la mano de otra serie de mecanismos y procesos que exceden los alcances de nuestro estudio.

En síntesis, la subjetivación política colectiva requirió complejos y constantes procesos de subjetivación estética que generaron aparecer(es) colectivos, exposiciones compartidas, comparecencias que no son meras escenificaciones de lo común, de lo que ya es, sino momentos constitutivos de la comunidad, del ser-juntos, donde lo colectivo adquiere posibilidad de ser. Así en el deber de todos de ser artistas, en la obligación del 
diseño de sí y de la experiencia colectiva se alojó una máquina estética de subjetivación política.

\section{Bibliografía}

\section{Fuentes impresas citadas}

AA.VV., Poéticas contemporáneas. Itinerarios de las artes visuales en la Argentina de los '90 al 2010, Buenos Aires, Fondo Nacional de las Artes, 2010.

Bajtin, Mijaíl, (1990) La cultura popular en la Edad Media y en el Renacimiento. El contexto de Francois Rabelais, Madrid, Alianza Editorial, 1990.

Balandier, Georges, El poder en escenas. De la representación del poder al poder de la representación, Barcelona, Paidós, 1994.

Blair, Elsa, Muertes violentas. La teatralización del exceso, Colombia, Universidad de Antioquia, 2005.

Benjamin, Walter, "La obra de arte en la época de su reproductibilidad técnica", Discursos interrumpidos I, Madrid, Taurus, 1973.

Carozzi, María Julia, "Antiguos difuntos y difuntos nuevos. Las canonizaciones populares en la década del 90”, en Daniel Míguez y Pablo Semán (eds.), Entre santos, cumbias y piquetes: las culturas populares de la Argentina reciente, Buenos Aires, Biblos, 2006.

Colectivo Situaciones (coord.), Impasse: dilemas políticos del presente, Buenos Aires, Tinta Limón, 2009.

Da Matta, Roberto, Carnavales, malandros y héroes. Hacia una sociología del dilema brasileño, México, Fondo de Cultura Económica, 2002.

De Certeau, Michel, The Practice of Everyday Life, Berkeley, University of California Press, 1984.

Deleuze, Gilles, Francis Bacon. Lógica de la sensación, Madrid, Arena Libros, 2009.

Didi-Huberman, George, Pueblos expuestos, pueblos figurantes, Buenos Aires, Manantial, 2014.

Di Filippo, Marilé, Logiódice, Julia y Lucca, Juan, "El ruido de lo popular: murga y política en Rosario", en Graciela Rocchi (comp.), Saliendo del barrio, Rosario, Ed. Laborde, 2013.

Diéguez Caballero, Ileana, Cuerpos sin duelo. Iconografías y teatralidades del dolor, Córdoba, DocumentA/Escénica Ediciones, 2013.

Dubatti, Jorge, Filosofía del teatro 2: cuerpo poético y función ontológica, Buenos Aires, Atuel, 2010.

Eco, Umberto, Ivanov, Vsévolod y Rector, Mónica, ¡Carnaval!, Buenos Aires, Fondo de Cultura Económica, 1989.

Expósito, Marcelo, "Desobediencia: la hipótesis imaginativa", en Jesús Carrillo y Juan Antonio Ramírez (eds.), Tendencias del arte. Arte de tendencias, Madrid, Cátedra, 2004.

__ "El arte no es suficiente", en Mariana Botey y Cuauhtémoc Medina (eds.), Estética y emancipación. Fantasma, fetiche, fantasmagoría, México, Siglo XXI, 2014.

Figari, Carlos, "Conocimiento situado y técnicas amorosas de la ciencia. Tópicos de epistemología crítica", Cinta de Moebio. Revista de Epistemología de Ciencias Sociales, Santiago, 2011.

Fornillo, Bruno, "Las estrategias políticas piqueteras autónomas en el contexto de reposicionamiento de la actividad estatal: la aparición del Frente Popular Darío Santillán", en IV Jornadas de Jóvenes Investigadores, Universidad de Buenos Aires, 2007. 
Gil, Javier, "De luces y sombras: a propósito de las estéticas comunitarias y colaborativas", Errata. Revista de Artes Visuales, N7, 2012, pp. 108-127.

Giunta, Andrea, Poscrisis. Arte argentino después de 2001, Buenos Aires, Siglo XXI, 2009.

Groys, Boris, Volverse público. Las transformaciones del arte en el ágora contemporáneo, Buenos Aires, Caja Negra Editora, 2014.

Haber, Alejandro, "Nometodología payanesa. Notas de metodología indisciplinada", Revista Chilena de Antropología, $\mathrm{N}^{\circ} 23$, Santiago de Chile, 2011, pp. 9-49.

Haraway, Donna, Ciencia, cyborgs y mujeres. La reinvención de la naturaleza, Madrid, Cátedra, 1995.

Herrera, María Rosa, "La contienda política en Argentina 1997-2002: Un ciclo de protesta", en América Latina Hoy, $\mathrm{N}^{\circ} 48,2008$, pp. 165-189.

Jacoby, Roberto, "La alegría como estrategia", Zona erógena, N 43, Buenos Aires, 2000.

Kozak, Claudia, Contra la pared: sobre graffitis, pintadas y otras intervenciones urbanas, Buenos Aires, Libros del Rojas, 2004.

Lipovetsky, Gilles y Serroy, Jean, La estetización del mundo. Vivir en la época del capitalismo artístico, Barcelona, Anagrama, 2015.

Longoni, Ana, "Activismo artístico en la última década en Argentina: algunas acciones en torno a la segunda desaparición de Jorge Julio López”, Errata, № 0, Bogotá, 2009, pp. 16-35.

Longoni, Ana y Bruzzone, Gustavo (comps.), El Siluetazo, Buenos Aires, Adriana Hidalgo, 2008.

Longoni, Ana, Lucena, Daniela y Risler, Julia, "Entrevista colectiva a Brian Holmes en Buenos Aires, Ramona, $\mathrm{N}^{\circ}$ 55, 2005.

Longoni, Ana y Mestman, Mariano, Del Di Tella a "Tucumán Arde". Vanguardia artística y política en el '68 argentino, Buenos Aires, El cielo por asalto, 2000.

Lucena, Daniela, Contaminación artística. Arte concreto, comunismo y peronismo en los años 40, Buenos Aires, Biblos, 2015.

Martín, Alicia, "Procesos de tradicionalización del carnaval de Buenos Aires", Cuadernos FHyCSUNJu, $\mathrm{N}^{\circ} 36,2009$, pp. 23-41.

Moret, Zulema, Artistas de lo que queda. Las escrituras de Escombros, Madrid, Trama Editorial, 2006.

Pacheco, Mariano, De Cutral-có a puente Pueyrredón. Una genealogía de los Movimientos de Trabajadores Desocupados, Buenos Aires, Ed. El Colectivo, 2010.

Rancière, Jacques, El desacuerdo. Política y filosofía, Buenos Aires, Nueva Visión, 2007.

-El reparto de lo sensible. Estética y política, Santiago, LOM, 2009.

-Sobre políticas estéticas, Barcelona, Universidad Autónoma de Barcelona, 2005.

Remedi, Gustavo, Murgas: el teatro de los tablados. Interpretación y crítica de la cultura nacional, Montevideo, Ediciones Trilce, 1996.

Ruby, Christian, Rancière y lo político, Buenos Aires, Prometeo Libros, 2011.

Svampa, Maristella, "Argentina: Una cartografía de las resistencias (2003-2008). Entre las luchas por la inclusión y las discusiones sobre el modelo de desarrollo", Observatorio Social de América Latina, Vol. X, Buenos Aires, CLACSO, 2008, 131 - 178.

"Argentina, una década después. Del 'que se vayan todos' a la exacerbación de lo nacionalpopular", Nueva Sociedad, N² 235, 2011, 17-34.

Vallverdú, Jaume, "Símbolos religiosos y acción colectiva: la 'mística' del movimiento de los trabajadores Rurales sin tierra (MST) de Brasil”, en Mónica Cornejo, Manuela Cantón y Ruy Llera Blanes (eds.), Teorías y prácticas emergentes en antropología de la religión, Donostia-San Sebastián, ANKULEGI antropología elkartea, Federación de Asociaciones de Antropología del Estado Español, 2008, 293-310. 
Uribe, María Victoria, Antropología de la inhumanidad. Un ensayo interpretativo sobre el terror en Colombia, Bogotá, Norma, 2004.

Vázquez, Cecilia, Prácticas artísticas de protesta y política en la ciudad de Buenos Aires 2003 2007, Tesis de Doctorado en Ciencias Sociales, Buenos Aires, Facultad de Ciencias Sociales de la Universidad de Buenos Aires, 2011.

Vich, Víctor, Poéticas del Duelo. Ensayos Sobre Arte, Memoria y Violencia Política en el Perú, Lima, Instituto de Estudios Peruanos, 2015.

\section{Fuentes documentales citadas}

Espacio de Cultura del FPDS, "Documento del 4 Plenario Nacional de Cultura", 2013. Figueroa, Noelia, "Acerca de piquetes y otras místicas populares”, escrito inédito, 2011. Movimento dos Trabalhadores Rurais Sem Terra, Método de trabajo popular. Cuaderno de formación $N^{o}$ 24, São Paulo, CONCRAB/MST, 2004.

\section{Fuentes digitalizadas citadas}

Chávez Mac Gregor, Helena, "Políticas de la aparición: estética y política", Academia.edu, https://www.academia.edu/.

Cocimano, Gabriel, "El sentido mítico y la metamorfosis de lo cotidiano en el carnaval", Gazeta de Antropología, $\mathrm{N}^{\circ} 17,2001$, http://www.gazeta-antropologia.es/?p=3318.

Longoni, Ana, “¿Tucumán sigue ardiendo?”, Sociedad, $\mathrm{N}^{\circ} 24,2005, \quad$ pp. 1-11, http://www.sociales.uba.ar/wp-content/uploads/17-Longoni.pdf. 